\title{
The Performance of Floating House Sub Structure in Tempe Lake
}

\author{
Rusdianto $^{\mathrm{a}, *}$, Nasruddin $^{\mathrm{b}}$, Hartawan Madeali $^{\mathrm{c}}$ \\ aArchitecture Department, Engineering Faculty, Hasanuddin University. Email:roesdi.a@ gmail.com \\ ${ }^{\mathrm{b}}$ Architecture Department, Engineering Faculty, Hasanuddin University. Email:nas_junus@ yahoo.com \\ cArchitecture Department, Engineering Faculty, Hasanuddin University. Email:hartawan@ unhas.ac.id
}

\begin{abstract}
This study aims to reveal the lifting power of the bamboo raft in holding the weight of the house on stilts so that it stays floating on the water. This research was conducted on the shores of Lake Tempe, precisely in Laelo Village, Tempe District, Wajo Regency. The method used in this research is a field study to determine the real situation in the field so that the real condition of the floating house is known. Furthermore, calculating the load used on the floating house based on the results of field studies. The final stage of the research is to test the raft lifting capacity of the floating house. The data will be analyzed according to Archimedes' Law, so that it can be seen that the bamboo raft can stay afloat even though it is given an Architectural building as heavy as a simple stilt house. The results of this study revealed that the average number of bamboos used as a raft was 175 stalks, and the mean diameter of bamboos was $7.67 \mathrm{~cm}$ or $0.077 \mathrm{~m}$. It is known that the volume of the rod segment cavity is $0.103 \mathrm{~m}^{3}$, so the total volume between sections on the floating raft on Lake Tempe is $18.058 \mathrm{~m}^{3}$. The lifting capacity of bamboo rafts is directly proportional to the volume of bamboo joints used as rafts. The experimental test results obtained revealed that the lifting capacity of bamboo per $\mathrm{m}^{3}$ was $874.51 \mathrm{~kg}$, so the lifting capacity of the bamboo raft in Tempe Lake was $18.058 \mathrm{~m}^{3} \times 874.51 \mathrm{~kg} / \mathrm{m}^{3}=15,789.13 \mathrm{~kg}$. While the results of the calculation of the burden of a simple house are known by calculating the house's own load and the living load experienced by the house, and the weight of the house is $9,314.121 \mathrm{~kg}$. With the ability to lift a bamboo raft of $15,789.13 \mathrm{~kg}$, the difference between the lifting capacity of the bamboo raft and the weight of the floating house is $6,475.01 \mathrm{~kg}$. The ideal number of bamboo culms is 129 with a safety factor of $25 \%$. There is an efficient use of 46 bamboo sticks.
\end{abstract}

Keywords: Floating house; house performance; lower structure

\section{Introduction}

Tempe Lake is located in three administrative areas, namely Kab. Wajo, Soppeng and Sidrap. Having a large enough area makes Tempe Lake a fishing area by the surrounding community. The people who work as fishermen then set up a residential unit on top of Lake Tempe. This residential unit was established to bring the distance between the house and the fishing work location closer. This house functions as a resting place and a place to store fishing gear equipment, because the intensity of the fishing community in Tempe Lake is longer than on land, even though they already have a house on the mainland.

According to Jumawan [1] the floating house on Lake Tempe was first introduced by fishermen looking for fish in Lake Tempe. The house made by the fishermen is similar to the traditional bugis stilt house. Iskandar [2] stated that people who live on water build houses with structures that can anticipate climate change conditions.

*Corresponding author. Telp. +62-821-9442-9038

Jalan Poros Malino km. 6 Bontomarannu

Gowa, Indonsia 92171
Some people use a raft system with wood and bamboo construction, such as those in the Musi River, Palembang, and the Barito River and Mahakam River in Kalimantan and in Lake Tempe, South Sulawesi [3].

In anticipating the climatic and environmental conditions in Lake Tempe, the community chose the raft system in the floating house structure. The system was chosen because the waters of Lake Tempe experience ups and downs according to climatic conditions, namely during the dry season, part of Lake Tempe waters will dry up, and in the rainy season, the lake water will overflow. This raft system is to make it easier for residential units to move according to water level [4]. The displacement of the residential unit follows climate change, during the dry season, when the lake water begins to decrease, the community settles into the middle of the lake, and moves to the shore of the lake during the rainy / flood season, which is when the water rises / overflows.

The floating house structure on Lake Tempe adopts the traditional Bugis stilt house structure, consisting of a lower, middle and upper structure. The uniqueness of this floating house structure is its substructure, which is a raft model made of bamboo. This bamboo raft serves as the 
building foundation on it. On top of the raft is placed a house on stilts which has low pillars, the central structure consists of a plank floor, lower tie beam (pattolo riawa), upper tie beam (arateng), floor and wall beams, while the upper structure consists of a roof frame and a covering.

The use of bamboo rafts as a building foundation and being able to withstand the loads on it is something interesting to study, especially in the study of the lifting capacity of bamboo rafts against the loads on it. Therefore, this study intends to reveal the lifting power of the bamboo raft in holding the load of the house on stilts so that it remains floating on the water.

\section{Literature Review}

\subsection{Performance}

Kusnadi's menuru performance is something he wants to achieve [5]. Whereas in English, performance is called performance which means action, implementation, performance. The word perform is used when someone performs a task or process skillfully in accordance with existing procedures or conditions.

\subsection{Data processing and analysis}

Structure is a system, which means a combination or series of various kinds of elements which are assembled in such a way as to become one unified whole. In buildings, structure is defined as a series of main materials (materials) that produce a particular form or form.

Wardhono [6] stated that the structure in building science is a means to transmit the load and the consequences of the use and / or presence of a building on / on the ground. Meanwhile, Schodek [7] said that the study of structure involves understanding the basic principles that show and characterize the behavior of physical objects which are influenced by forces. The structure of the building consists of parts of the building that point to vertical / upright and horizontal / flat lines / planes, as well as sloping lines / planes [8].

\subsection{Structure material}

The material forming the structure in the building is in the form of building materials that are mixed and arranged in such a way as to become the elements in the structure. As stated by Schodek [7] that an easy approach in classifying structures is based on the type of material (eg wood, steel, or reinforced concrete structures). Knowledge of this material will be felt because of the close relationship between the causes of the structure to deform (as a result of external loads), the material, and the construction method of the structure.

\subsection{Stability of the structure}

The basic review in planning the structure is to ensure stability under all possible loading conditions. All structures undergo a certain change of shape when loaded. In stable structures, the deformation caused by loads is generally small, and the internal forces arising in the structure have a tendency to return the structure to its original shape when the load is removed. In unstable structures, the deformation caused by loads generally tends to increase as long as the structure is loaded. An unstable structure does not exert internal forces which have a tendency to return the structure to its original shape. Unstable structures are prone to collapse completely and immediately become overburdened [7].

\subsection{Stability of the structure}

Faoji [9] said the pedestal is a place of placement for support for the construction in continuing the loads working towards the foundation. In construction science there are 3 types of pedestals, namely pinch supports, joint supports and roller supports.

\subsubsection{Pinch pedestals}

The pinch support is also known as a rigid support which reacts to horizontal and vertical forces and is able to react to torque rotation. On the pinch pedestal, there are 3 variables that can be solved ( $\mathrm{Rv}, \mathrm{Rh}$ and $\mathrm{M})$ as shown in Fig. 1.

\subsubsection{Support joints}

Joint support or hinge is a pedestal that works like a hinge. Support joints can withstand compressive forces and tensile forces from vertical and horizontal directions. On the pedestal there are two variables that can be solved ( $\mathrm{Rv}$ and $\mathrm{Rh}$ ) as shown in Fig. 2

\subsubsection{Roller support}

A roller support is a pedestal that slides horizontally. The support of the rollers cannot withstand horizontal forces and is only able to withstand the tensile and compression forces vertically. The roller supports also cannot withstand the moment or continue the moment, so that on this pedestal there is only 1 variable to be resolved $(\mathrm{Rv})$. So the roller support has only one reaction force that is perpendicular to the roller as shown in Fig. 3.

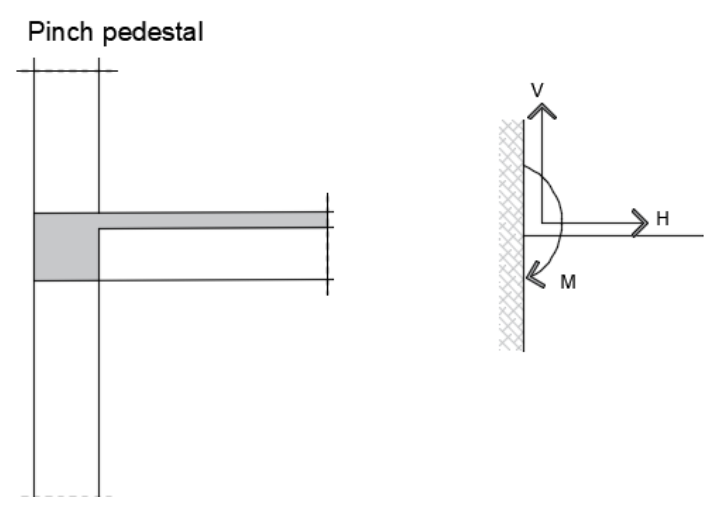

Figure 1. Clip pedestal

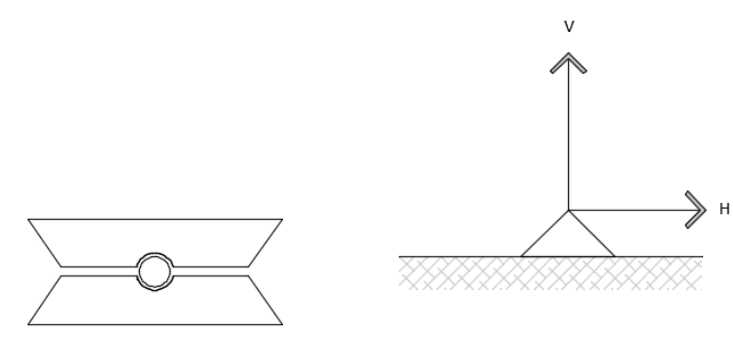

Figure 2. Support joints 


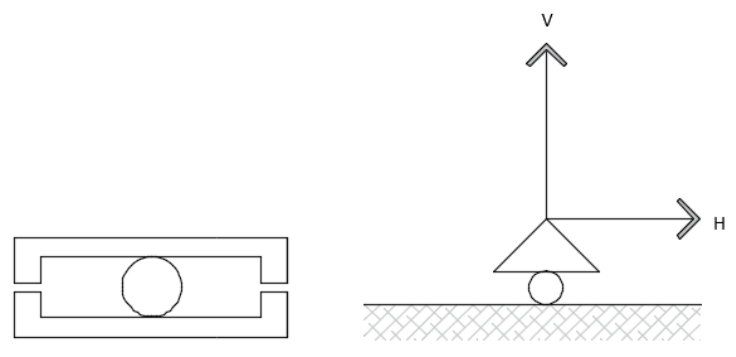

Figure 3. Roll support

\subsection{Floating house}

A floating house is a house that is above water and is floating, it is not permanent because it can move along with the tides and currents of the water. The existence of a floating house in the Lake Tempe area is an attempt by the community to approach their work location, because they are people who live from the waters in Lake Tempe. The floating house that is occupied is also a temporary house that functions not only for resting but also for storing fishing gear. This is confirmed by Naing [10], that fishing communities also have houses on land, but because fishermen activities in the waters take longer, people tend to live longer on water than on land.

\subsection{Floating house}

The shape of the floating house on Lake Tempe follows the shape of the Bugis stilt houses in general, which are commonly found in mainland areas. The basic difference between floating houses and houses on land is the base of the building, where the house on the mainland uses an umpak as its base, while the floating house on Lake Tempe uses a series of bamboo arranged to resemble a raft as its base.

The use of a raft as a building base has undergone a process of change according to the development needs of the fishing community at that time. As explained by Naing [11] that initially the community built kalampang (semipermanent shelter/shelter made of wood/bamboo) as a shelter from heat or rain and a place to store fishing gear.

\subsection{Floating house structure}

The structure of the floating house on Lake Tempe follows the structure of traditional Bugis houses in general. The traditional Bugis house has a basic structure as stated by Pelras, [9], that the Bugis house has a basic structure consisting of three times three pillars (three long rows of columns and three rows wide) in a rectangular shape with one pole at each corner, and on on each side there is a central pole called the 'navel house' (posi 'ball).

\subsection{Floating house structure}

The materials used by the Bugis people are local materials that are easily available in the natural environment and vary widely by region. Likewise with the house on stilts on the water, the material used is generally from wood that is easily available around the water.

Types of traditional building materials used by the Bugis are aju betti (bitti wood), aju ippi (ipi wood), aju amara (amara wood), aju sandalwood (sandalwood), aju tippulu (tippulu wood), aju durian (wood durian), aju panasa (wood panasa), aju seppu (iron wood), palm sticks, coconut stems, bamboo, palm sticks, pindang stems, grass leaves and fibers. The use of this material depends on the ability and availability of funds for the home owner.

\subsection{Floating house structure}

Bamboo is one of the main materials in making floating house rafts in Tempe Lake. this is because bamboo material has long been known by the community, it is very easy to obtain and the price is relatively cheap. Ndale [12] explained that in Indonesia there are more than 13 species of bamboo which are commonly used by the community as building materials. Bamboo types in Indonesia are shown in Table 1.

Bamboo is a type of plant that is included in the Bamboidae which is a member of the grass sub-family, so it grows very fast. In addition, Janssen [13] describes the advantages and disadvantages of using bamboo. The advantages of using bamboo are that bamboo grows very fast and can be cultivated by the population, has good mechanical properties, the process requires simple tools and the outer shell contains a lot of silica which can protect bamboo. While the disadvantages are that bamboo requires preservation to obtain a long term of use, the shape of bamboo stalks is not exactly a cylinder but rather conical and bamboo is flammable.

Furthermore, Ndale [12] explained that bamboo is not prismatic in shape with a narrow cross section at the top, and has an unequal spacing of nodes along the stem. In one bamboo stick consists of the outer skin, outer bamboo, middle bamboo, inner bamboo.

Table 1. Types of bamboo in Indonesia [9]

\begin{tabular}{ll}
\hline \multicolumn{1}{c}{ Local Name } & \multicolumn{1}{c}{ Scientific Name } \\
\hline $\begin{array}{l}\text { Thorn bamboo, gesing } \\
\text { bamboo, greng bamboo, haur } \\
\text { cucuk, pring greng }\end{array}$ & $\begin{array}{l}\text { Bambusa Spinosa } \\
\text { Bluemeana }\end{array}$ \\
\hline Bamboo thorn, pring ori & Bambusa Bambos Cruce \\
\hline $\begin{array}{l}\text { Awi krisik, chinese bamboo, } \\
\text { pring gendani, pring cendani, } \\
\text { bamboo fence }\end{array}$ & $\begin{array}{l}\text { Bambusa Multiplex } \\
\text { Reausech }\end{array}$ \\
\hline $\begin{array}{l}\text { Bamboo spotted, jajang ivory, } \\
\text { awi koneng }\end{array}$ & Bambusa Vulgaris Schrad \\
\hline $\begin{array}{l}\text { Awi betung, petung bamboo, } \\
\text { delin peting, jajang betung, } \\
\text { pring petung }\end{array}$ & $\begin{array}{l}\text { Dendrocalamus Asper } \\
\text { (Schult, F) Black ex Heyne }\end{array}$ \\
\hline $\begin{array}{l}\text { Andong gombong, awi } \\
\text { gombong, awi hideung, black } \\
\text { bamboo, pring wulung, } \\
\text { pereng sorat }\end{array}$ & $\begin{array}{l}\text { Gigantochloa Verticillite } \\
\text { (Willa) Munro }\end{array}$ \\
\hline $\begin{array}{l}\text { Longan bamboo, awi tela, } \\
\text { longan bamboo }\end{array}$ & Gigantochloa Nigrociliata \\
\hline $\begin{array}{l}\text { Awi tali, bamboo tali, deling } \\
\text { apus, pring tali, Pring Lear }\end{array}$ & Gigantochloa Apus \\
\hline $\begin{array}{l}\text { Awi long rope, awi tela } \\
\text { pring wuluh, reed blowgun }\end{array}$ & $\begin{array}{l}\text { Gigantochloa Hasskarlina } \\
\text { (kurz) Back ex Heyne }\end{array}$ \\
\hline $\begin{array}{l}\text { Bamboo perling, awi } \\
\text { cakeutreauk }\end{array}$ & $\begin{array}{l}\text { Phyllostashyum Aurea } \\
\text { Schizostashyum Zollingeri }\end{array}$ \\
\hline Awi fur & $\begin{array}{l}\text { Schizostashyum } \\
\text { Branchycladium Kurz }\end{array}$ \\
\hline
\end{tabular}




\subsubsection{Outer skin}

The outer skin is the outermost or topmost part, usually green or black. The thickness of the bamboo skin is relatively uniform along the length of the stem, namely \pm $1 \mathrm{~mm}$, it is hard and stiff.

\subsubsection{Outer bamboo}

This part is located under the skin or between the outer and middle skin. The thickness of this section is $\pm 1 \mathrm{~mm}$, it is hard and stiff.

\subsubsection{Middle part}

The middle part is located under the outside or between the outside and the inside, also called bamboo meat. The thickness is $2 / 3$ the thickness of bamboo, and it is dense and elastic. For the middle part of the bottom, the fiber is a bit coarse.

\subsubsection{The inside of the bamboo}

The inside is the bottom part of the thick bamboo, often called the bamboo heart. The nature of the fiber is stiff and breaks easily.

Besides that, Morisco [14], also explained that bamboo has joints and books. Roots will also grow on these segments so that it is possible to multiply the plant from the pieces of each segment, in addition to the rhizome shoots.

Ndale [12], said that the specific gravity of bamboo is the ratio of the weight of bamboo to the weight of a volume of water which is equal to the volume of the bamboo. Furthermore, Handayani [15], said that the density and density of wood or bamboo are factors that will determine its physical and mechanical properties. This is because the density and density of bamboo are determined by the amount of wood substance. Bamboo density ranges from $0.5-0.9 \mathrm{gr} / \mathrm{cm}^{3}$.

\subsection{Lifting power in water}

According to Archimedes [16], an object that is partially or completely immersed in water or other liquid will experience an upward force equal to the weight of the liquid being moved. The magnitude of this buoyancy depends on the amount of water the object is pushing. The greater the water being pushed, the greater the buoyancy force. When an object is immersed in a liquid, then there is 3 possibilities that occur, namely sinking, floating, and floating.

\subsubsection{Submerged object}

An object is said to be immersed in liquid if the object's position is always on the bottom where the liquid is as shown in Fig. 4. In submerged objects there are three forces, namely:

$$
\begin{aligned}
& W=\text { the object's gravity } \\
& F a=\text { Archimedes style } \\
& N=\text { normal force of the plane }
\end{aligned}
$$

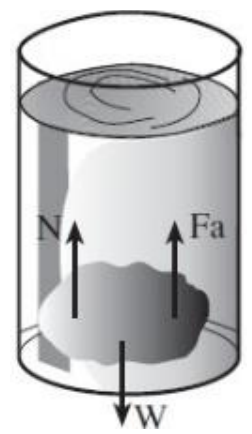

Figure 4. The sunken object [16]

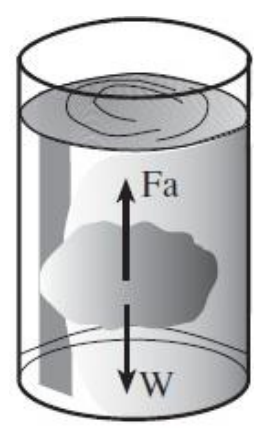

Figure 5. Floating object [16]

In a balanced state, $W=N+F a$ so that:

$$
W>F a
$$

$$
\begin{aligned}
m \cdot g & >\rho Z C \cdot V b \cdot g \\
\rho b \cdot V b \cdot g & >\rho Z C \cdot V b \cdot g \\
\rho b & >\rho Z C
\end{aligned}
$$

where

$$
\begin{aligned}
& \rho b=\text { density of the object } \\
& \rho Z C=\text { density of the liquid }
\end{aligned}
$$

\subsubsection{Floating object}

Objects float in liquid when the position of the object is below the surface of the liquid and above where the liquid is as shown in Fig. 5. In floating objects there are two forces, namely $F a$ and $W$, in a balanced state:

$$
W=F a
$$

$$
\begin{aligned}
\rho b \cdot V b \cdot g & =\rho Z C \cdot V b \cdot g \\
\rho b & =\rho Z C
\end{aligned}
$$

\subsubsection{Things float}

An object floats in a liquid when the position of the object partly appears on the surface of the liquid and partly immersed in the liquid as shown in Fig. 6. 


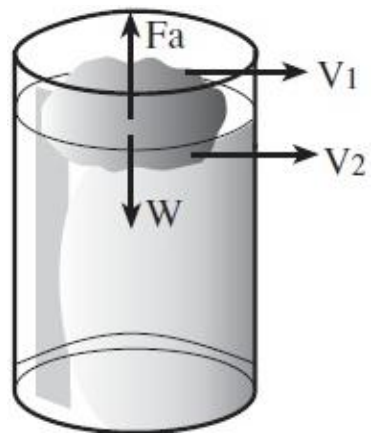

Figure 6. Things float [16]

Floating objects have two forces, namely: Fa and W, in a balanced state, then:

$$
W<F a
$$

$$
\begin{gathered}
\rho b \cdot V b \cdot g<\rho Z C \cdot V_{2} \cdot g \\
\qquad b \cdot V b<\rho Z C \cdot V_{2} \\
\text { because } V b<V 2 \text { then } \rho b=\rho Z C
\end{gathered}
$$

\section{Research Methods}

This research was conducted by using field survey methods, literature studies and experimental tests. The variable studied was a bamboo raft in a floating house on Lake Tempe. The research object chosen was a floating house with a simple and natural construction and approaching the shape of a Bugis stilt house. Experimental tests were carried out by making a bamboo raft model that was placed in the water, then gradually given the load on it. Each additional load will affect the water level, so it can be seen the buoyancy force of the bamboo raft. The analysis of buoyancy is based on Archimedes' Law which states that the magnitude of the buoyancy is equal to the weight of the liquid that is being pushed (moved).

\section{Results and Discussion}

Based on the results of surveys and field observations and interviews with residents, it can be seen that the floating house which is the object of the research has been established for 10 years and has experienced the addition and replacement of bamboo on the raft 3 times gradually, according to the level of damage to the bamboo. The following image shows the shape of the floating house which is the object of research.

The lifting capacity of a bamboo raft to a floating house is based on the ability of a bamboo raft to stay afloat even when given the weight of a simple house. To determine the lifting capacity, this research was carried out by testing the load giving to the bamboo raft.

The raft model made from dried bamboo and cut to a length of $300 \mathrm{~cm}$, then immersed in a water pool with a size of $688 \times 100 \times 70 \mathrm{~cm}$. This pool is filled with water as high as $26 \mathrm{~cm}$. When the bamboo raft is put into a pool filled with water, it floats. This happens because the density of bamboo is less than the density of water. As stated by Ndale, 2013, that the specific gravity of bamboo ranges from $0.5-0.9 \mathrm{gr} / \mathrm{cm}^{3}$. While the specific gravity of water is $1 \mathrm{~g} / \mathrm{cm}^{3}$, meaning that bamboo can float in the water.

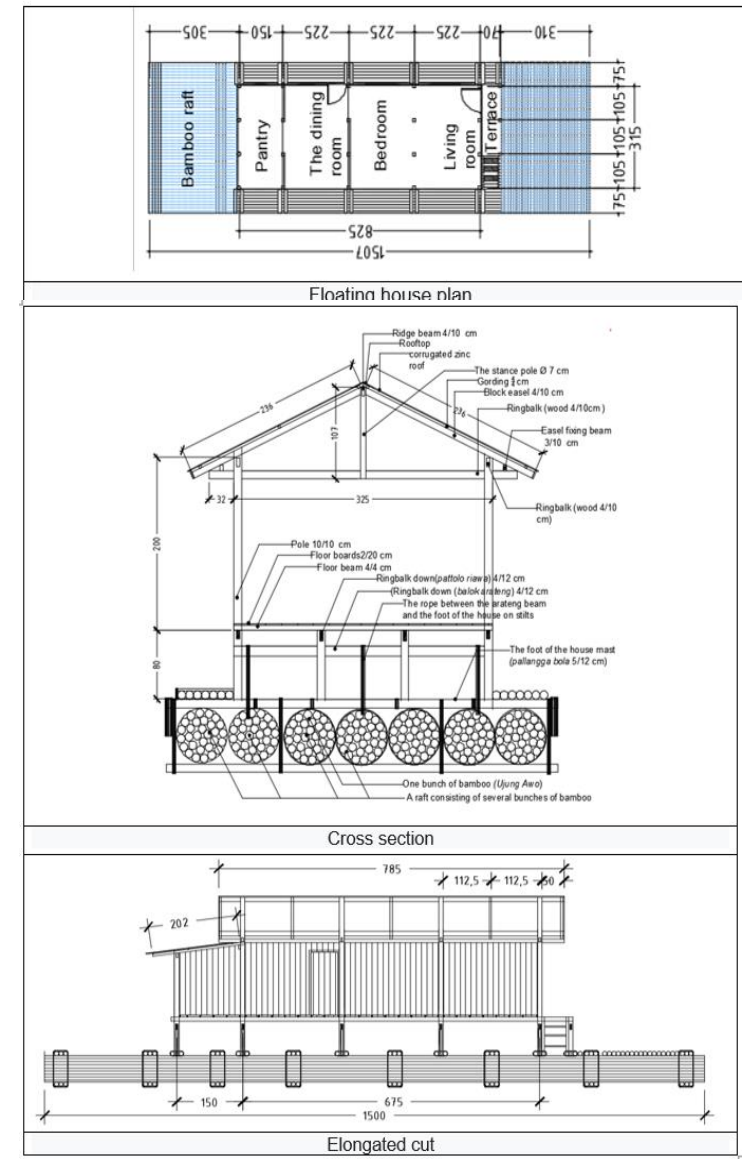

Figure 7. Sketches of floating houses as research objects

The buoyancy of bamboo culms is also influenced by the volume of the cavity between the closed sections of bamboo. Inside the cavity contains air so that it affects the density of the bamboo.

Experimental tests were carried out using 10 pieces of bamboo with a length of $300 \mathrm{~cm}$ and the volume of different sections because the diameter of the bamboo was different and so were the lengths of the sections. The calculated segment volume is the volume of the inner and closed cavity, so that water cannot enter. The differences in the volume of these sections are shown in the following table.

Table 2. Results of calculation of cavity volume in experimental bamboo sections

\begin{tabular}{cccccc}
\hline & & \multicolumn{4}{c}{ Bamboo dimensions } \\
\cline { 3 - 6 } No & Descr. & $\begin{array}{c}\text { Inner Dia. } \\
\text { of Bamboo } \\
(\mathbf{m})\end{array}$ & $\begin{array}{c}\text { Segments } \\
\text { Average } \\
\text { Length (m) }\end{array}$ & $\begin{array}{c}\text { No of } \\
\text { Segments } \\
\text { /Stems }\end{array}$ & $\begin{array}{c}\text { Volume of } \\
\text { Segments } \\
\left(\mathbf{m}^{\mathbf{3}}\right)\end{array}$ \\
\hline 1 & Bamboo 1 & 0.067 & 0.484 & 5 & 0.009 \\
2 & Bamboo 2 & 0.058 & 0.463 & 6 & 0.007 \\
3 & Bamboo 3 & 0.054 & 0.495 & 5 & 0.006 \\
4 & Bamboo 4 & 0.070 & 0.435 & 6 & 0.010 \\
5 & Bamboo 5 & 0.057 & 0.328 & 9 & 0.008 \\
6 & Bamboo 6 & 0.059 & 0.482 & 6 & 0.008 \\
7 & Bamboo 7 & 0.069 & 0.502 & 5 & 0.009 \\
8 & Bamboo 8 & 0.062 & 0.458 & 6 & 0.008 \\
9 & Bamboo 9 & 0.062 & 0.326 & 8 & 0.008 \\
10 & Bamboo 10 & 0.050 & 0.486 & 5 & 0.005 \\
\hline
\end{tabular}


The ten pieces of bamboo were then formed into a raft, starting from the first 2, 3, 4, to 5. Then the final raft is made of 10 sticks composed of 2 bundles containing 5 bamboo sticks each.

In testing, each raft that was made was placed into a pool that was filled with water. When the raft is placed into a pool filled with water, the water level of the pool rises, which indicates that there is pressure on the pool water. Likewise, when the raft is given loads gradually.

Experiment 1 was carried out using a raft of 2 bamboo sticks (bamboo 1 and 2). When the raft is put into the pool, the water level becomes $0.261 \mathrm{~m}$. Then the raft was given a load of $4.30 \mathrm{~kg}$ in stages, then added by $4.24 \mathrm{~kg}$, so that the total load given to the raft of 2 bamboo sticks weighing $8.54 \mathrm{~kg}$ was obtained. As a result of the load, the water level changes to $0.262 \mathrm{~m}$ at load 1 and $0.263 \mathrm{~m}$ after the load is added.

Followed by experiment 2, using a raft of 3 bamboo sticks (bamboo 1, 2 and 3). Then experiment 3 with 4 bamboo stalks, experiment 4 with 5 bamboo sticks and experiment 5 with 10 bamboo sticks consisting of 2 bundles containing 5 bamboo sticks each.

In experiment 5, from the results of the calculations presented in table 1 , it is known that the average inner diameter is $\pm 0.061 \mathrm{~m}$, the length (distance between) sections is $\pm 0.45 \mathrm{~m}$, the total volume of cavity of the bamboo segment used is $0.077 \mathrm{~m}^{3}$. The experimental results can be seen in the Fig. 8 .

The graph in Figure 8 above shows the change in the water level of the pool after inserting the bamboo raft and adding the load gradually on it. Changes in the water level of the pool depend on the number of bamboos made into the raft and the weight of the loads placed on the raft. The change in the water level of the pool indicates that the more bamboo is made into a raft and the heavier the load is added to the raft, the greater the volume of water pressed. The amount of water volume pressed is influenced by the weight of the bamboo and the additional load on the experimental bamboo raft.

Based on Archimedes' Law which states that when an object is immersed in a liquid, either partially or completely, the object will get a buoyancy (upward force) which is equal to the weight of the liquid being pushed (moved) by the object. This means that any change in the water level in the experimental pool can be said to be the magnitude of the buoyancy force of objects in the water.

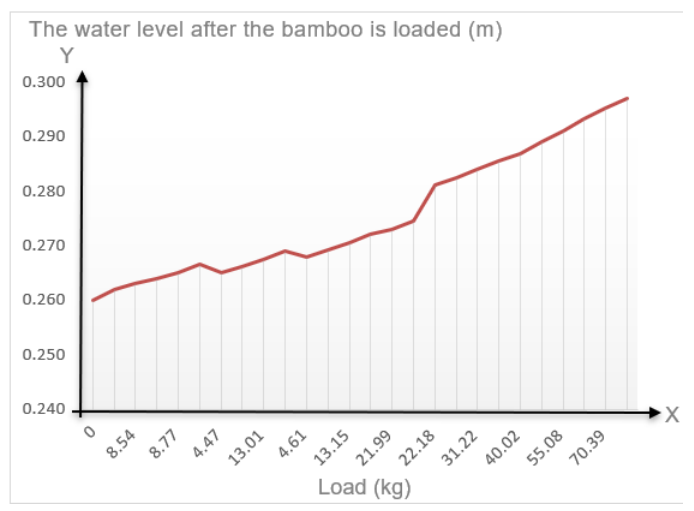

Figure 8. Graph of changes in pool water level
Therefore, in an effort to obtain bamboo lifting capacity, it is necessary to know the volume of water pressed due to the insertion of the bamboo raft into the pool and the load on the raft, because the volume of water pressed is equal to the weight of the bamboo raft and the load given to it.

Table 2 explains that the more bamboo is put into the pond, the greater the volume of water pressed. Likewise, the heavier the load added on the bamboo, the greater the volume of water pressed as shown in Table 3 . The volume of water pressed is influenced by the weight of the bamboo raft and the additional load on the raft. The volume of water that is pressed is the difference from the volume of water increase due to the load on the bamboo raft that is inserted into the pond with the volume of pool water before being treated.

Furthermore, to obtain the lifting capacity of the bamboo raft in the above experiment, the difference in the volume of pressed water in each experiment is multiplied by the density of water, where it is known that the density of water is $1 \mathrm{~g} / \mathrm{cm}^{3}$ or $1000 \mathrm{~kg} / \mathrm{m}^{3}$.

Based on the results of the calculations shown in Table 4 , it can be seen that from the experimental results, the average lift capacity on a bamboo raft is $874.51 \mathrm{~kg} / \mathrm{m}^{3}$.

Table 3. Results of the calculation of the volume of pressed water

\begin{tabular}{|c|c|c|c|c|}
\hline \multirow[t]{2}{*}{ No } & $\begin{array}{c}\text { Number of } \\
\text { bamboo stems }\end{array}$ & $\begin{array}{c}\text { Bamboo } \\
\text { raft } \\
\text { weight }\end{array}$ & Load & $\begin{array}{c}\text { Volume of } \\
\text { water } \\
\text { pressed } \\
\end{array}$ \\
\hline & Ties (1-2 ties) & (kg) & (kg) & $\left(\mathrm{m}^{3}\right)$ \\
\hline \multirow{2}{*}{1} & \multirow{2}{*}{$\begin{array}{c}2 \text { bamboo sticks } \\
\text { ( } 1 \text { bunch })\end{array}$} & 7.56 & 4.30 & 0.00681 \\
\hline & & 7.56 & 8.54 & 0.01110 \\
\hline \multirow{3}{*}{2} & \multirow{3}{*}{$\begin{array}{c}3 \text { bamboo sticks } \\
\text { ( } 1 \text { bunch })\end{array}$} & 13.18 & 4.30 & 0.00681 \\
\hline & & 13.18 & 8.77 & 0.01362 \\
\hline & & 13.18 & 13.01 & 0.02384 \\
\hline \multirow{4}{*}{3} & \multirow{4}{*}{$\begin{array}{c}4 \text { bamboo sticks } \\
\text { (1 bunch) }\end{array}$} & 19.13 & 4.47 & 0.00749 \\
\hline & & 19.13 & 8.71 & 0.01430 \\
\hline & & 19.13 & 13.01 & 0.02384 \\
\hline & & 19.13 & 17.62 & 0.03374 \\
\hline \multirow{6}{*}{4} & \multirow{6}{*}{$\begin{array}{c}5 \text { bamboo sticks } \\
\text { (1 bunch })\end{array}$} & 23.64 & 4.61 & 0.00681 \\
\hline & & 23.64 & 8.91 & 0.01984 \\
\hline & & 23.64 & 13.15 & 0.02452 \\
\hline & & 23.64 & 17.62 & 0.03406 \\
\hline & & 23.64 & 21.99 & 0.04019 \\
\hline & & 23.64 & 26.48 & 0.05040 \\
\hline \multirow{10}{*}{5} & \multirow{10}{*}{$\begin{array}{c}10 \text { bamboo sticks } \\
\text { ( } 2 \text { bunch) }\end{array}$} & 47.01 & 22.18 & 0.04867 \\
\hline & & 47.01 & 26.67 & 0.05108 \\
\hline & & 47.01 & 31.22 & 0.06130 \\
\hline & & 0.077 & 35.72 & 0.07517 \\
\hline & & 47.01 & 40.02 & 0.08053 \\
\hline & & 47.01 & 47.60 & 0.09536 \\
\hline & & 47.01 & 55.08 & 0.10898 \\
\hline & & 47.01 & 62.85 & 0.12464 \\
\hline & & 47.01 & 70.39 & 0.13827 \\
\hline & & 47.01 & 75.00 & 0.14985 \\
\hline
\end{tabular}


Table 4 . The results of the calculation of the lifting capacity of bamboo rafts

\begin{tabular}{|c|c|c|c|c|}
\hline \multirow[t]{2}{*}{ No } & \multirow[t]{2}{*}{$\begin{array}{c}\text { Number of } \\
\text { bamboo stems }\end{array}$} & $\begin{array}{c}\text { Urgent } \\
\text { volume of } \\
\text { water }\end{array}$ & $\begin{array}{l}\text { Bamboo } \\
\text { lifting } \\
\text { power }\end{array}$ & $\begin{array}{c}\text { Bamboo } \\
\text { lifting } \\
\text { power is } \\
\text { average }\end{array}$ \\
\hline & & $\left(\mathrm{m}^{3}\right)$ & (kg) & $\left(\mathrm{kg} / \mathrm{m}^{3}\right)$ \\
\hline \multirow{2}{*}{1} & \multirow{3}{*}{$\begin{array}{l}2 \text { bamboo sticks } \\
\text { (1 bunch) }\end{array}$} & 0.00681 & 6.81 & 429.21 \\
\hline & & 0.01110 & 11.10 & 699.62 \\
\hline \multirow{3}{*}{2} & & 0.00681 & 6.81 & 316.29 \\
\hline & \multirow{3}{*}{$\begin{array}{l}3 \text { bamboo sticks } \\
\text { (1 bunch) }\end{array}$} & 0.01362 & 13.62 & 632.59 \\
\hline & & 0.02384 & 23.84 & $1,107.03$ \\
\hline \multirow{4}{*}{3} & & 0.00749 & 7.49 & 237.30 \\
\hline & \multirow{4}{*}{$\begin{array}{l}4 \text { bamboo sticks } \\
\text { (1 bunch) }\end{array}$} & 0.01430 & 14.30 & 453.02 \\
\hline & & 0.02384 & 23.84 & 755.03 \\
\hline & & 0.03374 & 33.37 & $1,057.04$ \\
\hline & & 0.00681 & 6.81 & 167.29 \\
\hline \multirow{4}{*}{4} & \multirow{4}{*}{$\begin{array}{l}5 \text { bamboo sticks } \\
\text { (1 bunch) }\end{array}$} & 0.01984 & 14.98 & 368.03 \\
\hline & & 0.02452 & 24.52 & 602.23 \\
\hline & & 0.03406 & 34.06 & 836.43 \\
\hline & & 0.04019 & 40.19 & 986.98 \\
\hline \multirow{12}{*}{5} & \multirow{11}{*}{$\begin{array}{c}10 \text { bamboo } \\
\text { sticks ( } 2 \text { bunch) }\end{array}$} & 0.05040 & 50.40 & $1,237.91$ \\
\hline & & 0.04867 & 40.87 & 530.34 \\
\hline & & 0.05108 & 51.08 & 662.92 \\
\hline & & 0.06130 & 61.30 & 795.51 \\
\hline & & 0.07517 & 71.52 & 928.09 \\
\hline & & 0.08053 & 81.05 & $1,051.84$ \\
\hline & & 0.09536 & 95.36 & $1,237.46$ \\
\hline & & 0.10898 & 108.98 & $1,414.24$ \\
\hline & & 0.12464 & 124.64 & $1,617.53$ \\
\hline & & 0.13827 & 138.27 & $1,794.31$ \\
\hline & & 0.14985 & 149.85 & $1,944.57$ \\
\hline & Lifting & wer is aver & & 874.51 \\
\hline
\end{tabular}

Table 5. Data on bamboo rafts on floating houses in Lake Tempe

\begin{tabular}{|c|c|c|c|}
\hline No & Description & Volume & Unit \\
\hline 1 & The amount of bamboo used & 175 & stem \\
\hline 2 & Length of bamboo in stem & 15 & $\mathrm{~m}$ \\
\hline 3 & Inner diameter of stem section & 8 & $\mathrm{~cm}$ \\
\hline 4 & Inner diameter of the middle & 9 & $\mathrm{~cm}$ \\
\hline 5 & Inner diameter of the end & 6 & $\mathrm{~cm}$ \\
\hline 6 & The length of the bamboo segment & 43 & $\mathrm{~cm}$ \\
\hline 7 & $\begin{array}{l}\text { The average number of segments in } \\
\text { one stem }\end{array}$ & 29 & section \\
\hline
\end{tabular}

Meanwhile, to determine the lifting capacity of the bamboo raft to the floating house in Lake Tempe, it is done by multiplying the total volume of bamboo knots with the average lifting capacity of bamboo per cubic meter. From the field survey conducted at the research location, data is obtained as presented in Table 5.

From the data in Table 5, it is known that the mean diameter of the hollow sections of bamboo is $7.67 \mathrm{~cm}$ or $0.077 \mathrm{~m}$ and the number of bamboo sections per stick is 29 sections. So the volume of a bamboo segment per stem is $0.77 \times 29=0.104 \mathrm{~m}^{3}$. Meanwhile, the total volume of hollow sections of bamboo used in the floating house raft in Tempe Lake is $0.104 \mathrm{~m} 3 \times 175$ rods $=18.058 \mathrm{~m}^{3}$. Then the lifting capacity of the bamboo raft in the floating house is $18.058 \mathrm{~m}^{3} \times 874.51 \mathrm{~kg} / \mathrm{m}^{3}=15,789.13 \mathrm{~kg}$.

Meanwhile, the results of the calculation of the weight of the house are known by calculating the house's own load and the living load experienced by the house, and the results of the house weight are 9,314.121 kg. With the ability to lift a bamboo raft in a floating house of 15,789.13 $\mathrm{kg}$, the number of bamboo sticks that should be used in making bamboo rafts at floating houses in Lake Tempe are:

$$
\begin{aligned}
& J b 2 \div B r A=J b 1 \div D a R b \\
& J b 2 \div 9.314,121 \mathrm{~kg}=175 \div 15.789,12 \mathrm{~kg} \\
& J b 2=1.629 .971,18 \mathrm{~kg} \div 15.789,13 \mathrm{~kg} \\
& J b 2=103,23 \approx 104 \text { stem }
\end{aligned}
$$

From the calculation above, it is found that the number of bamboo sticks that should be used in the floating house in Tempe Lake is 104 sticks.

\section{Conclusion}

The magnitude of this buoyancy depends on the amount of water that is pushed (moved) by the object. Based on the test, it was found that the greater the cavity volume of the bamboo segment, the greater its lifting capacity. Lifting power is obtained by calculating the difference in the volume of water in a pond that has been filled with bamboo and given a load with the volume of water in the pool without any load on the bamboo. Furthermore, the difference in the volume of water pressed is multiplied by the density of the water and divided by the number of stages of giving the load, then the average lifting capacity of bamboo is obtained to be $874.51 \mathrm{~kg} /$ $\mathrm{m}^{3}$.

In the research object, namely the floating house on Lake Tempe, with 175 bamboo rods used as rafts, with an average diameter of $7.67 \mathrm{~cm}$ or $0.077 \mathrm{~m}$, the volume between the sections per rod was $0.103 \mathrm{~m}^{3}$. So the total volume between sections on the floating house raft at Lake Tempe is $0.103 \mathrm{~m} 3 \times 175$ rods $=18.058 \mathrm{~m}^{3}$, so that the bamboo raft lift capacity is $18.058 \mathrm{~m}^{3} \times 874.51 \mathrm{~kg} / \mathrm{m}^{3}=$ $15,789.13 \mathrm{~kg}$.

\section{Acknowledgements}

Thanks are conveyed to the supervisors and thesis examiners, as well as the lecturers and staff at the Department of Architecture, Faculty of Engineering, Hasanuddin University. Especially to parents, wife, children and siblings for all their support and prayers.

\section{References}

[1] Jumawan, Faris. 2017. Tempe Lake Fishermen's Residence, Soppeng Regency. Celebes Media Perkasa. Makassar.

[2] Iskandar, Yulindiani. 2010. Local Wisdom in the Completion of Structure and Construction of Raft Houses on the Musi River Palembang. Lokal Wisdom (Local Wisdom Scientific Online Journal). Volume II, Number 2, pages 37-45, March 2010. 
[3] Naing, Naidah. 2009. Traditional Local Wisdom of Fishermen Communities in Floating Settlements on Lake Tempe, South Sulawesi. Lokal wisdom (Local Wisdom Scientific Oline Journal), volume 1, number 1 pages 19-26, March 2009

[4] Naidah. 2011. Moving Settlements in a Floating House System as a Process of Human Adaptation to the Environment in Lake Tempe, South Sulawesi. Postgraduate Dissertation, Sepuluh November Institute of Technology, Surabaya.

[5] Kusnadi. Complete Dictionary of Indonesian Language (latest edition). CV Cahaya Agency. Surabaya.

[6] Wardhono, Uniek Praptiningrum. 2009. Architectural Glossary. Dictionary of Terms in Architecture. Publisher Andi Yogyakarta

[7] Schodek, Daniel L. 1998. Structure. Publisher PT. Refika Aditama. Bandung.

[8] Tangoro, Dwi. 2015. Building Science. High Span and Tall Building Structures. Publisher UI Press. Jakarta.

[9] Faoji, Ahmad, 2018. Comparison of Fixed and Pinned on Structures Power House is Reviewed from Material Efficiency and Costs (Case Study of Peaker Seram PLTMG Project)
[10] Naing, Naidah,2011. Moving Settlements in a Floating House System as a Process of Human Adaptation to the Environment in Lake Tempe, South Sulawesi. Postgraduate Dissertation, Sepuluh November Institute of Technology, Surabaya.

[11] Naing, Naidah,2011. Bugis Floating House. Nusa Cendekia Publisher, printed I, November 2018.

[12] Ndale, Fransiscus. 2013. Sifat Fisik dan Mekanik Bambu sebagai Bahan Konstruksi. Jurnal Teknik Universitas Flores. Volume 7. Nomor 2. Oktober 2013

[13] Janssen J.J.A., 1980, The Mechanical Properties of Bamboo Used in Cuntruction, 173 - 188. In Lessard, G. \& Chouinard, A. Bamboo Research in Asia, IDRC, Canada.

[14] Morisco, 1999, Bamboo Engineering, Nafiri Offset, Yogyakarta.

[15] Handayani, 2007. Bamboo Mechanical Properties Testing. Journal of Civil Engineering and Planning no.1, volume January 9, 2007.

[16] Untoro, Joko. 2009. SMA Physics Smart Books for Grades 1, 2 and 3. Wahyu Media Publisher. Jakarta. 